\title{
A STUDY OF THE DISTRIBUTION AND FATE OF ANTIMONY WHEN USED AS TARTAR EMETIC AND FUADIN IN THE TREATMENT OF AMERICAN SOLDIERS WITH SCHISTOSOMIASIS JAPONICA
}

\author{
By STUART W. LIPPINCOTT, ${ }^{1}$ LESTER D. ELLERBROOK, ${ }^{2}$ MARK RHEES, ${ }^{3}$ \\ AND PORTER MASON 4 \\ (From the Department of Pathology, University of Washington School of Medicine, Seattle)
}

(Received for publication August 27, 1946)

During the Leyte campaign in the Philippines a number of American soldiers were infected by the cercariae of Schistosoma japonicum. While under observation at Harmon General Hospital, 138 out of 495 such previously treated patients were found to be passing eggs in their stools and were, therefore, treated again either with tartar emetic or fuadin. The purpose of this report is to present data on the concentrations of antimony attained in body fluids under given dosages of these drugs, together with the amount and rate of excretion in urine and stool. Reference is also made to the therapeutic efficiency of the chemical regimes employed.

\section{MATERIAL AND METHODS}

\section{Treatment}

Patients found to have the eggs of Schistosoma japonicum in their stools were given in rotation, and without regard to previous treatment overseas, equivalent amounts of antimony ( $0.566-0.576 \mathrm{gram})$ in the form of fuadin or tartar emetic (freshly prepared or commercially prepared). One $\mathrm{ml}$. of the fuadin solution contained 0.0087 gram antimony and $1 \mathrm{ml}$. of tartar emetic solution 0.0018 gram antimony. Fuadin was given by the intramuscular injection of a 6.3 per cent solution, beginning with daily doses of $1.5,3.5$, and $5.0 \mathrm{ml}$. and continuing with $5.0 \mathrm{ml}$. doses on alternate days until a total of $65 \mathrm{ml}$. had been given over a period of 25 days (33 patients). Tartar emetic was given by the intravenous injection of a 0.5 per cent solution on alternate days, beginning with doses of $8,12,16$, and $24 \mathrm{ml}$. and continuing with $24-\mathrm{ml}$. doses until a total of $320 \mathrm{ml}$. had been given in 29 days ( 77 patients). Subsequently 15 patients were treated with a course of $105 \mathrm{ml}$. of fuadin ( 0.914 gram antimony) and 31 patients with $416 \mathrm{ml}$. of tartar emetic ( 0.748 gram antimony). The total number of courses of treatment was 156, but this included some

\footnotetext{
1 Lt. Colonel, MC.

2 Major, SnC.

${ }^{8}$ First Lieut., SnC.

4 Lt. Colonel, MC.
}

patients with 2 courses of treatment. The times at which various specimens were taken are shown in appropriate tables and figures.

\section{Method of analysis}

The method of Maren (1) has been slightly modified in order to make it more sensitive and specific, and the modified method has been applied to the determination of microgram quantities of antimony in body fluids. Maren states that the blank is of the order of 0.4 microgram and that the iron in blood interferes by giving still larger blanks. The limit of the method in the absence of iron is stated to be 0.5 microgram. When 5 -gram specimens of blood are analyzed, he substracts 1 microgram from the final value to compensate for the iron blank. Such a procedure seems inadvisable, especially when the quantity of antimony in the specimen being examined is itself often considerably less than the 1 microgram value being subtracted.

It has been found that the blank may be reduced by the use of chemicals of the proper degree of purity, and it may be eliminated by reading the optical density of the unknown against reagent blanks instead of against benzene. The blank produced by iron has been eliminated by precipitating the iron as ferric-ferrocyanide during the color development. The precision of the method has been further improved by developing the color rapidly at a nearly constant low temperature, by minimizing the fading of the developed color caused by sunlight, and by including specimens of known antimony content along with each lot of unknowns and calculating the unknown values accordingly.

\section{Reagents}

The reagents used were those given by Maren with the following exceptions :

$a$. Mallinckrodt phosphoric acid was the only one of several brands found to give low consistent blanks.

b. Potassium ferrocyanide $2 \mathrm{grams}$ in $100 \mathrm{ml}$. of 0.02 per cent Rhodamine B solution.

c. Hydrochloric acid $6 \mathrm{~N}$ containing $1 \mathrm{mgm}$. of ferric iron per $\mathrm{ml}$.

\section{Digestion}

$a$. Ten ml. or smaller specimens of blood, plasma, urine, or bile are digested according to Maren's directions. 
b. Stool: To 5 grams of stool are added $6 \mathrm{ml}$. of sulfuric acid and $10 \mathrm{ml}$. of nitric acid. Digestion with nitric acid is carried out in the usual way. Remove the solution from the hot plate, add 2 drops of perchloric acid and immediately put back on the hot plate, in order to eliminate spattering due to the presence of precipitated salts. The solution is cooled after the appearance of copious $\mathrm{SO}_{3}$ fumes and is diluted with $46 \mathrm{ml}$. of water giving a 1-10 dilution containing insoluble salts $(2 \mathrm{ml}$. of sulfuric acid are boiled off during the digestion). Place 1 to $5 \mathrm{ml}$. of this well-mixed dilution into a $125-\mathrm{ml}$. flask and add $3 \mathrm{ml}$. of sulfuric acid.

\section{Reduction}

Maren's procedure is used.

\section{Color development}

In order to obtain the maximum color and consistent results, it is essential to develop the color as rapidly as possible at a low temperature and to keep the colored extracts out of direct sunlight. The reagents and glassware used are kept in ice water until used. To the digest flask in an ice water bath, add $5 \mathrm{ml}$. of $6 \mathrm{NHCl}$ and mix. When the mixture is cold, add 2 drops of $0.02 \mathrm{~N}$ ceric sulfate and mix. After 2 minutes add $8 \mathrm{ml}$. of $3 \mathrm{~N}$ phosphoric acid and $5 \mathrm{ml}$. of 0.02 per cent Rhodamine B. Mix and pour all of the mixture into a cold $50-\mathrm{ml}$. glass-stoppered bottle containing $10 \mathrm{ml}$. of cold benzene. Shake 200 times in order to extract the red antimony-dye complex. Aspirate off the aqueous layer, decant the benzene layer into a cuvette, and centrifuge about 5 minutes. Since the optical density was proportional to the concentration only when 0 to approximately 5 micrograms of antimony were present, specimens containing more than 5 micrograms were extracted with 20 or $30 \mathrm{ml}$. of benzene instead of 10 $\mathrm{ml}$., and the results obtained were corrected accordingly.

Because of the small daily variation of color intensity due to varying speeds of color development and room and water temperature, standards were prepared daily by adding known amounts of antimony to normal plasma, blood, et cetera, and carrying these through the entire procedure concurrently with the unknowns. The digestion process was included in the preparation of the standards in order to compensate for possible traces of contaminants in the large amounts of acid used and for the small loss due to spattering during the digestion (probably less than 5 per cent). Reagent blanks and plasma, blood, and other blanks were also prepared in a similar manner.

\section{Note on blood and feces}

The reduced blood digest contains a precipitate of iron salts which interferes in the subsequent color development probably by adsorbing some of the colored complex. This precipitate is dissolved by adding $6 \mathrm{ml}$. of $4.5 \mathrm{~N}$ sulfuric acid and boiling the mixture until $\mathrm{SO}_{3}$ fumes begin to appear. The yellowish-green solution remains clear and becomes almost colorless on cooling, but precipitation will again occur after several hours. The iron now in solution in the blood digest interferes by giving a blank; so it must be removed in order to obtain precise results. This iron may be removed by precipitation as ferric ferrocyanide, but in the presence of less than $2 \mathrm{mgm}$. of iron, low recoveries are sometimes obtained, presumably because of adsorption of the colored complex on the semicolloidal precipitate. In the last 2 sets of determinations, excellent results were obtained by adding enough iron to insure the development of a quickly-flocculating precipitate.

The final changes in the regular procedure when applied to blood are as follows: After reduction the iron salts are first brought into solution. The hydrochloric acid used contains $1 \mathrm{mgm}$. of ferric iron per $\mathrm{ml}$. (total $5 \mathrm{mgm}$.). In order to prevent the precipitation of some of the potassium ferrocyanide by the strong acid present in the digest, this reagent is added in combination with the Rhodamine $B$ as a 2 per cent solution. Under these conditions the precipitation is complete and almost instantaneous. Blanks to which have been added as much as $\mathbf{5} \mathrm{mgm}$. of iron give readings practically identical with those obtained in the absence of iron.

In stools, interference by precipitated salts in the digest was partially eliminated by adding $2 \mathrm{ml}$. of water after the reduction and heating as with the blood digest. Color was developed in the usual manner with the exception that $12 \mathrm{ml}$. of phosphoric acid were used to help prevent the precipitation of salts during the process. It is believed that any slight interference by the presence of small amounts of iron can be prevented by following the procedure used with blood.

\section{Calculations}

The optical densities are read in $19 \mathrm{~mm}$. cuvettes on a Coleman Junior Spectrophotometer at a wave length of $565 \mathrm{mu}$. Reagent blanks, prepared by carrying $5 \mathrm{ml}$. of water through the entire procedure, usually gave transmittance readings of approximately 98.7 per cent against benzene at 100 per cent. The reagent blanks are set at 100 per cent, and the unknown are read against them. The plasma standards are read against the plasma blanks set at 100 per cent because of the possible presence of traces of antimony in the plasma used. The optical density of the unknown is divided by the optical density per microgram of antimony present in the standard to give the number of micrograms of antimony present in the sample.

\section{Precision of the method}

The precision of the method may be gauged by the data in Table $I$, in which are recorded the results of recovery experiments done in the last 4 series of determinations of the antimony concentrations of plasma, red blood cells, urine and feces made during a period of over 1 month. The mean error of the plasma recoveries in a range of 1-5 micrograms was 3 per cent. The mean error of the other recoveries was approximately 5 per cent, although the variations encountered on some of these particular days were somewhat greater than usual. 
TABLE I

Recovery of added antimony in successive series of determinations

\begin{tabular}{|c|c|c|c|c|c|c|c|c|}
\hline $\begin{array}{l}\text { Anti- } \\
\text { mony } \\
\text { added }\end{array}$ & Date & Plasma (5 ml.) & Date & Urine (5 ml.) & Date & Feces (0.5 gram) & Date & Blood (5 ml.) \\
\hline $\begin{array}{c}\begin{array}{c}\text { micro- } \\
\text { grams }\end{array} \\
0.5 \\
1.0 \\
3.0 \\
5.0 \\
1.0 \\
3.0 \\
5.0 \\
1.0 \\
3.0 \\
5.0 \\
1.0 \\
3.0 \\
5.0\end{array}$ & $\begin{array}{l}11 / 15 \\
11 / 16 \\
12 / 1 \\
12 / 3\end{array}$ & $\begin{array}{l}\text { per cent of average } \\
D=0.0717 \\
\text { (2) } 103 \pm 1 \\
(2) 99 \pm 1 \\
(2) 99 \pm 2 \\
D=0.0691 \\
\text { (2) } 101 \pm 0 \\
(2) 99 \pm 4 \\
D=0.0635 \\
(1) 93 \\
(2) 103 \pm 3 \\
(2) 100 \pm 3 \\
D=0.0690 \\
\text { (2) } 96 \pm 1 \\
\text { (2) } 107 \pm 1 \\
\text { (2) } 97 \pm 0\end{array}$ & $\begin{array}{l}10 / 31 \\
11 / 7 \\
11 / 20 \\
11 / 28\end{array}$ & $\begin{array}{l}\text { per cent of average } \\
D=0.0684 \\
\text { (2) } 100 \pm 0 \\
\text { (2) } 101 \pm 0 \\
\text { (2) } 99 \pm 0 \\
D=0.0689 \\
\text { (2) } 102 \pm 9 \\
\text { (1) } 99=1 \\
\text { (2) } 99 \pm 1 \\
D=0.0695 \\
\text { (2) } 109 \pm 13 \\
\text { (2) } 103 \pm 3 \\
(2) 88 \pm 7 \\
D=0.0674 \\
\text { (2) } 100 \pm 2 \\
\text { (2) } 100 \pm 2 \\
\text { (2) } 100 \pm 2\end{array}$ & $\begin{array}{l}11 / 6 \\
11 / 9 \\
11 / 19 \\
12 / 3\end{array}$ & $\begin{array}{l}\text { per cent of average } \\
D=0.0677 \\
\text { (1) } 103 \\
\text { (1) } 98 \\
\text { (1) } 100 \\
\text { (1) } 98 \\
D=0.0677 \\
\text { (1) } 95 \\
\text { (1) } 102 \\
\text { (1) } 102 \\
D=0.0720 \\
\text { (1) } 104 \\
\text { (1) } 99 \\
\text { (1) } 97 \\
D=0.0634 \\
\text { (2) } 90 \pm 5 \\
\text { (2) } 110 \pm 1 \\
\text { (2) } 100 \pm 3\end{array}$ & $\begin{array}{l}11 / 24 \\
11 / 27 \\
11 / 22 \\
12 / 3\end{array}$ & $\begin{array}{c}\text { per cent of average } \\
\mathrm{D}=0.0614 \\
\\
(2) 91 \pm 6 \\
(2) 98 \pm 2 \\
(2) 110 \pm 3 \\
\mathrm{D}=0.0702 \\
(2) 103 \pm 3 \\
(2) 100 \pm 0 \\
(2) 97 \pm 6 \\
\mathrm{D}=0.0631 \\
(2) 103 \pm 0 \\
(2) 97 \pm 15 \\
(2) 100 \pm 3 \\
\mathrm{D}=0.0687 \\
1 \mathrm{ml} .(2) 102 \pm 3 \\
10 \mathrm{ml} .(1) 88 \\
1 \mathrm{ml} \text { (2) } 103 \pm 2 \\
10 \mathrm{ml} \text {. (2) } 103 \pm 4\end{array}$ \\
\hline & & $\begin{array}{c}\text { Average error } 3 \text { per cent } \\
\text { Range }-7 \text { per cent to } \\
+8 \text { per cent }\end{array}$ & & $\begin{array}{l}\text { Average error } 4 \text { per cent } \\
\text { Range }-18 \text { per cent to } \\
+22 \text { per cent }\end{array}$ & & $\begin{array}{l}\text { Average error } 5 \text { per cent } \\
\text { Range }-15 \text { per cent to } \\
+11 \text { per cent }\end{array}$ & & $\begin{array}{l}\text { Average error } 5 \text { per cen } t \\
\text { Range }-15 \text { per cent to } \\
+13 \text { per cent }\end{array}$ \\
\hline
\end{tabular}

$\mathrm{D}=$ Average optical density per microgram of added antimony.

()$=$ Number of determinations.

\section{RESULTS}

\section{Plasma concentrations}

Plasma antimony concentrations were determined at various intervals during and after treatment with both tartar emetic and fuadin. The average pre-dose 48-hour values are shown in Figure 1. At the beginning of treatment the average concentration was about 8 micrograms per liter probably as a result of previous courses of treatment. As the course of treatment progressed the plasma concentrations increased rather rapidly to about 85 micrograms per liter after 3 weeks of treatment, and then more slowly to a final concentration of approximately 100 micrograms per liter. The concentrations in the fuadin group increased more rapidly in the early stages of treatment because larger amounts of antimony were given at this time. When the 2 groups of values are compared on the basis of the total amount of antimony administered by each particular time, they are nearly identical. Apparently, equal amounts of antimony given as either tartar emetic or fuadin in approximately equal periods of time result in nearly identical equilibrium plasma antimony concentrations.

After the discontinuance of treatment both groups of plasma concentrations decreased at about the same rate. By 6 days after the final dose
(4 days after the 48-hour equilibrium level had been attained) the average concentrations had decreased by about 35 per cent, at 12 days by 52 per cent, and at 28 days by 80 per cent. At 100 days after the end of treatment the average plasma concentration was still 7 micrograms per liter, nearly identical with the pre-treatment value.

The variations of the plasma, blood cell, and urine concentrations at intervals of from $15 \mathrm{~min}$ utes to 6 hours after administration of the first dose, the first maximum dose, and 3 other doses including the last one were studied in groups of 4 patients being treated with each drug. The results obtained are shown in Figures 2 and 3 . As one would suspect, the maximum plasma concentration was found at the 15-minute interval for tartar emetic and somewhat later for fuadin. The tartar emetic values dropped rather rapidly to nearly the equilibrium levels, but the fuadin plasma concentrations dropped more slowly. The latter values were considerably greater than those of the tartar emetic group at each time interval, although by 4 hours they were approaching the equilibrium values. Apparently, tartar emetic is removed from the plasma more rapidly than is fuadin.

\section{Blood cell concentrations}

At all stages of treatment with both drugs the concentration of antimony in the blood cells was 


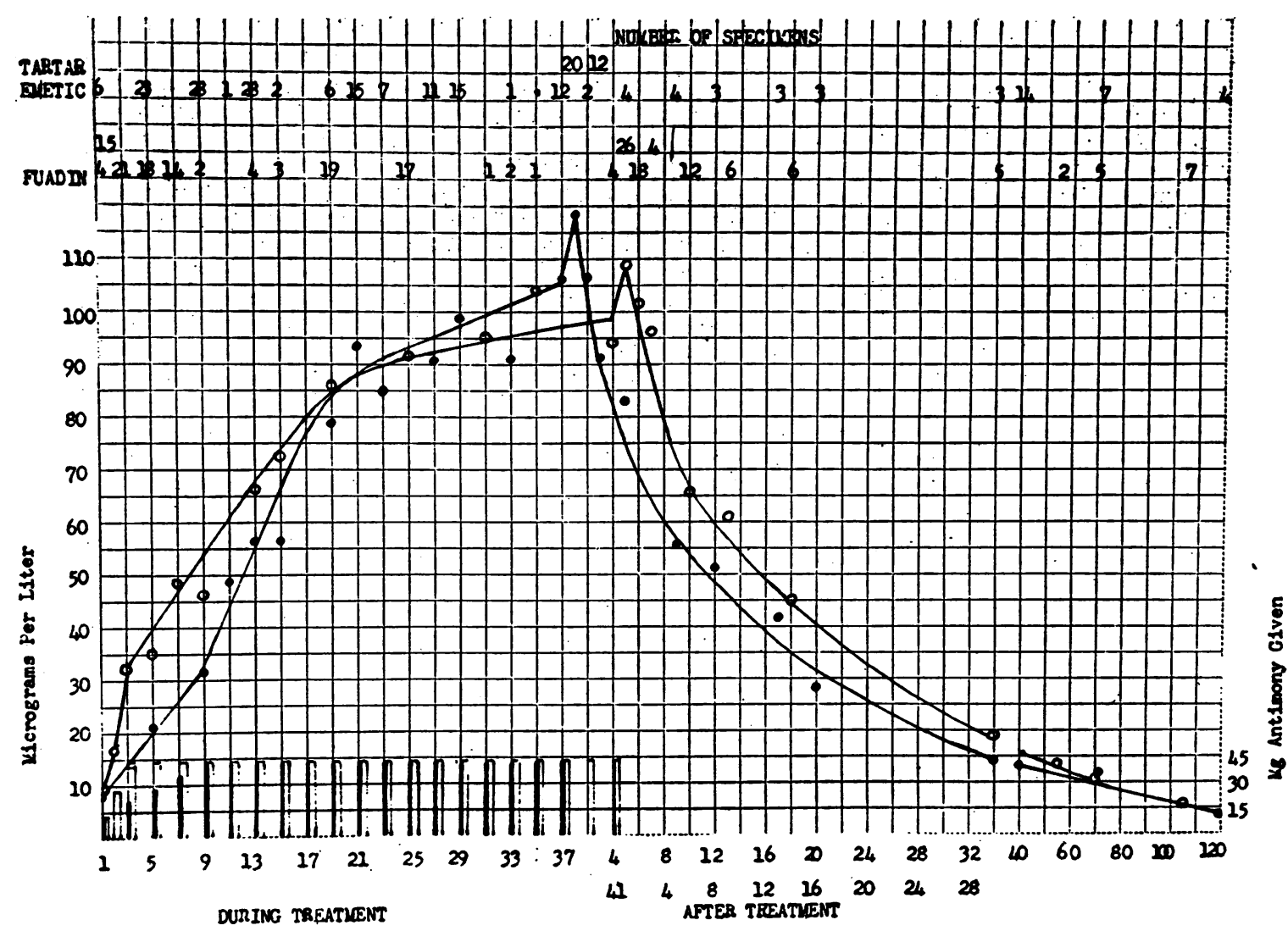

TARTAR ERETIC-Solid bars and dots. FUADIN-Open bars and circles.

Fig. 1. Average Pre-dose Plasma Antimony Concentrations During and After Treatment

definitely greater than that in the corresponding plasma, although the cell-plasma ratios varied during and after the courses of treatment. In the case of tartar emetic the pre-dose cell-plasma ratio decreased from a value of approximately 4 just before treatment to about 1.7 at the completion of treatment. The average pre-dose (48-hour) cell concentrations on various days of treatment were as follows: Day 1,$29 ; 5,77 ; 9,94 ; 13,105 ; 19$, $138 ; 27,157 ; 29,183$; and 37,195 micrograms per liter. After treatment the cell-plasma ratios again increased with the average cell concentrations being as follows : Day 2,$214 ; 3,182 ; 6-10,103$; 39, $49 ; 72,39$; and $110,47$.

The pre-dose cell-plasma ratios in the fuadin group varied from about 4 on day 3 of treatment to approximately 1.8 after day 10 . The pre-dose cell concentrations on various days were as follows: Day 3, 126; 5, 51 ; 9, 82; 13, $134 ; 19,133$; 25,182 ; and 41,165 micrograms per liter. After treatment the ratios again increased to about 4 at 70 days with the average cell concentrations being as follows: Day 1,$215 ; 2,186 ; 3,206 ; 6,131$; 35,68 ; and 70, 45.

The variations in blood cell concentrations at short intervals after the administration of doses of the drugs were considerably different in the 2 groups. In the tartar emetic group the maximum cell concentrations at 15 minutes were $7-15$ times the pre-dose levels and were $6-8$ times greater than the plasma concentrations at the same times. The cell concentrations decreased by approximately 50 per cent in the ensuing 45 minutes and more slowly thereafter so that the average cell-plasma ratio at 4 hours was about 10 after the first dose and 3 at the end of treatment.

With fuadin, the cells reached their peak antimony concentrations at about the time of the maximum plasma concentrations. The cell concentrations rose somewhat higher than did those 


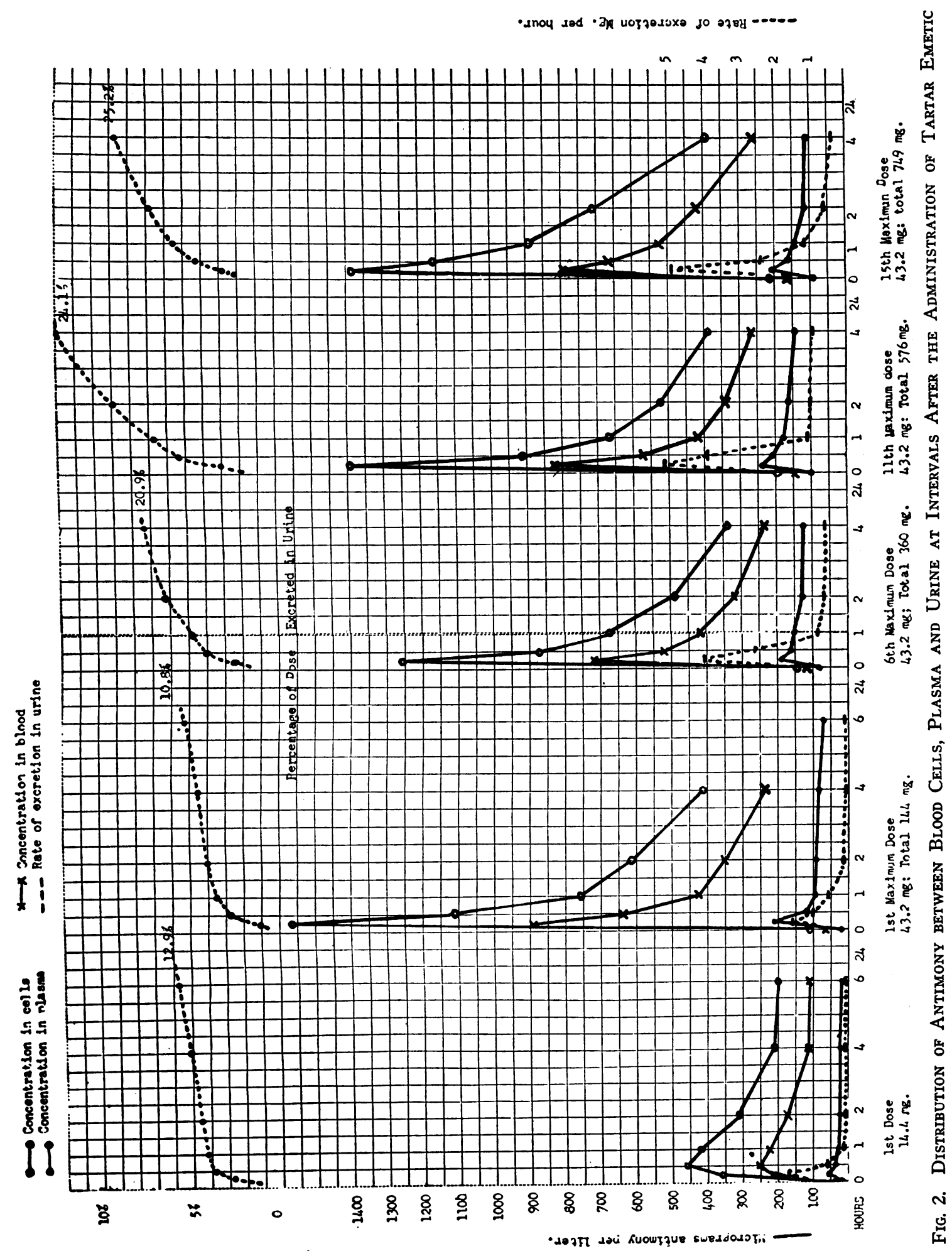




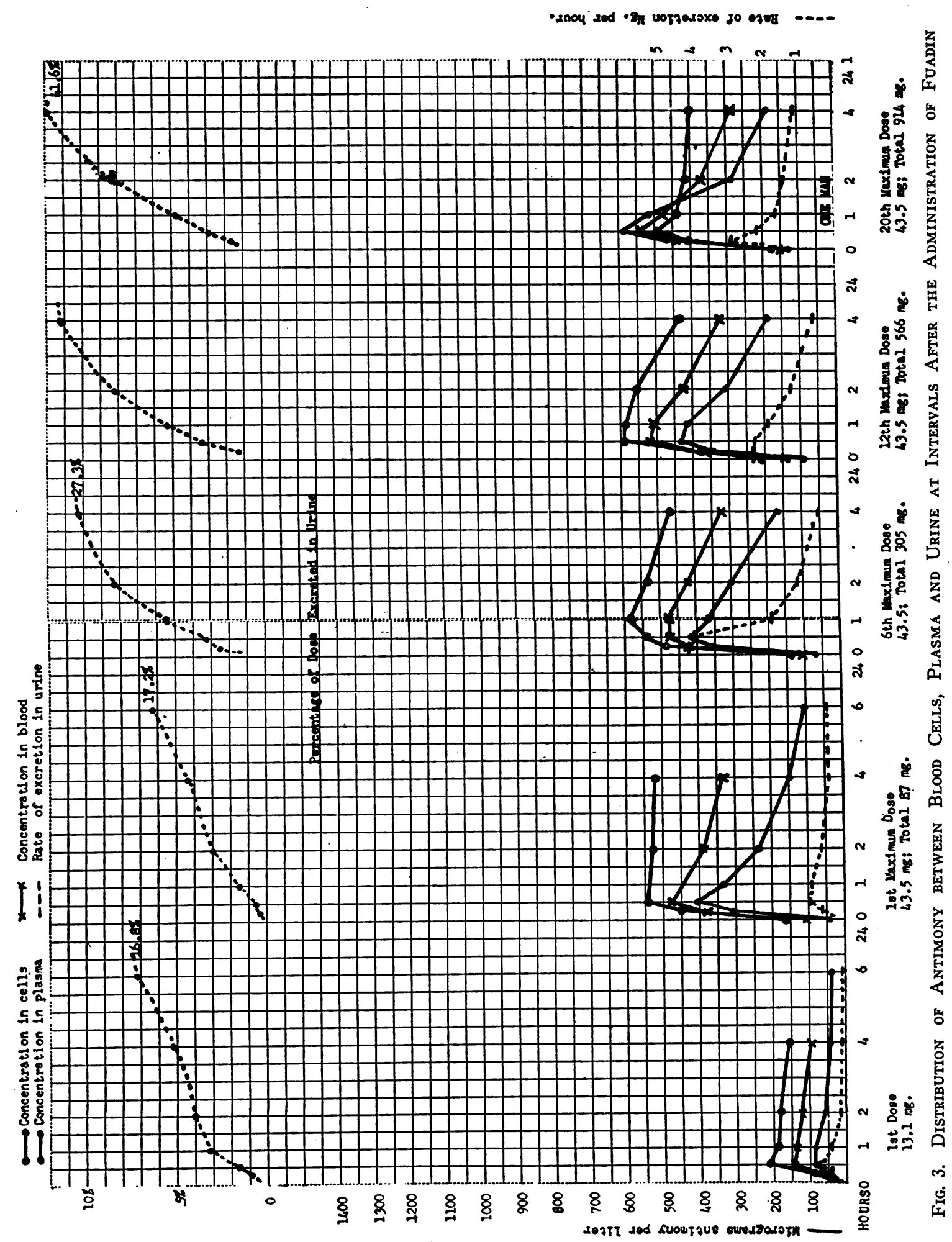


of plasma and they dropped slightly more slowly. The peak concentrations were roughly half as great as those found with tartar emetic and they decreased more slowly so that by 4 hours they were approximately the same as the tartar emetic values. The maximum cell concentrations were 3-4 times the pre-dose levels and were 1-4 times greater than the plasma concentrations at the same times. The average cell-plasma ratio at 4 hours was approximately 3 .

Apparently, the early, more rapid decrease of the plasma concentration in the tartar emetic group is at least partially due to a more rapid uptake of tartar emetic by the blood cells. Subsequently this antimony is transferred somewhere else without appreciably affecting the plasma antimony concentration.

\section{Excretion in urine}

In Figures 4 and 5 are plotted the average 24hour antimony excretions of a few patients at different times during and after treatment. For comparative purposes are shown the average plasma concentrations of larger groups of patients at 2 or at 4 hours after drug administration and also 24 hours later. As is to be expected, the plasma concentration and the urinary excretion on the day of drug administration were greater than on the following day. The excretion increased from nearly $2 \mathrm{mgm}$. on the day of the first dose to approximately $6 \mathrm{mgm}$. on the day of the first full dose, to roughly $10 \mathrm{mgm}$. per day in the latter part of the treatment period. There were no marked differences in the 24-hour excretions of these 2 small groups, although the fuadin values tended to be slightly greater. At approximately 40 days after completion of treatment the average daily excretion was still roughly $1 \mathrm{mgm}$. per day in both groups while at about 100 days $0.2 \mathrm{mgm}$. was being excreted per day.

The average urinary antimony excretions of the 4 men in each group studied at short intervals after drug administration are also shown in Figures 2 and 3 . In the tartar emetic group the maximum rate of excretion was found in the first 15-minute period at the time of the maximum plasma and blood cell concentrations. The rate rapidly decreased to a fairly constant level by 1 to 2 hours after the dose. The actual urinary antimony concentrations did not follow the same pattern for

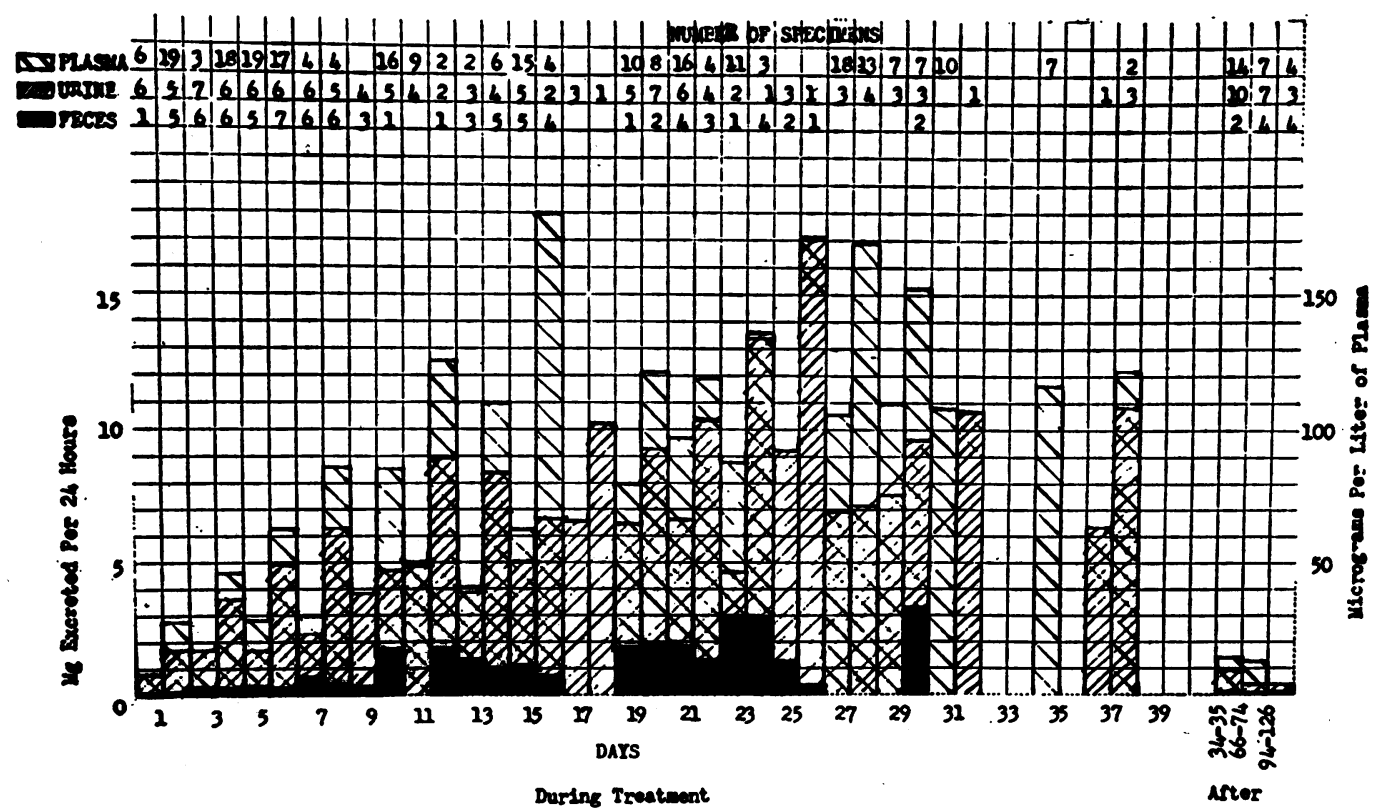

Plase - 2 bowre arter dose

Fig. 4. Comparison of Antimony Excretion with Plasma Concentration During and After Treatment with Tartar EMetic 


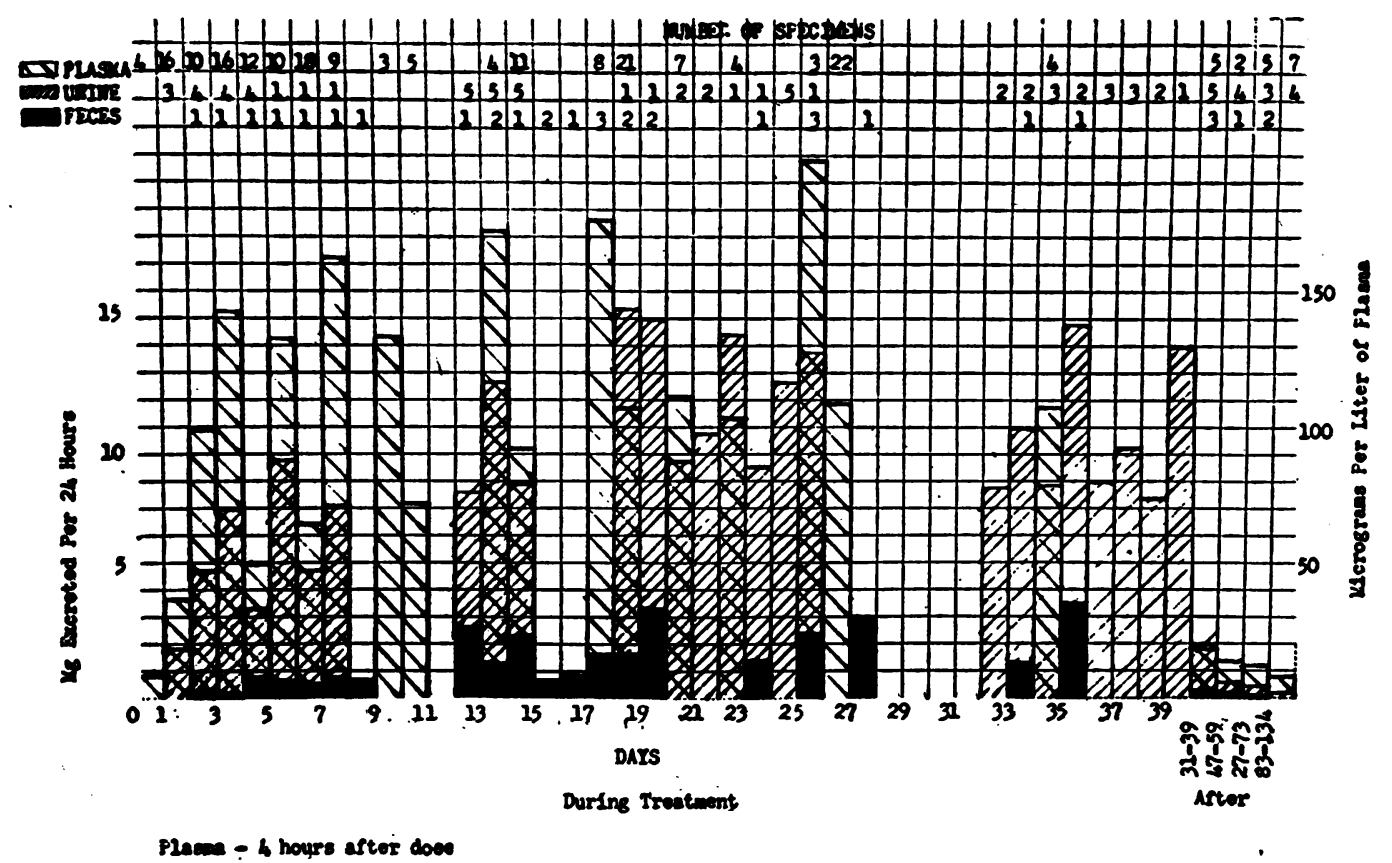

Fig. 5. Comparison of Antimony Excretion with Plasma Concentration During and After Treatment with Fuadin

they tended to be smaller in specimens with larger volumes and lower specific gravities. In a few cases the forcing of fluids before and shortly after drug administration had no marked effect upon the rate of urinary antimony excretion. The average excretion in the first 15 minutes was about 3 per cent of the injected dose; in the first 2 hours it was 6 per cent and the 24-hour excretions ranged from approximately 12 per cent at the beginning of treatment to 25 per cent at the end of treatment.

In the fuadin group the maximum rate of excretion occurred at about the time of the peak plasma concentration. As a rule the maximum rates were lower than those of the tartar emetic group, but the rates of excretion decreased more slowly so that after about 2 hours they were greater than the corresponding tartar emetic rates. The actual urinary antimony concentrations in this group also varied with.the specific gravities of the specimens. The average excretion in the first 15 minutes was about 1.3 per cent of the injected dose; in the first 2 hours the excretions increased from about 4 per cent after the first dose to 8 per cent after the last dose. The 24-hour excretions increased from about 17 per cent after the first dose to 27 per cent after the sixth maximum dose, and in one case to 42 per cent after the twentieth maximum dose.

\section{Excretion in feces}

In Figures 4 and 5 are shown the average 24hour excretions in a limited number of specimens. The average excretion varied from about $0.5 \mathrm{mgm}$. per day during the first week of treatment to approximately $2 \mathrm{mgm}$. daily toward the end of treatment. Small amounts were still being excreted at more than 100 days after the completion of treatment.

The combined excretion in urine and feces toward the end of treatment was roughly $24 \mathrm{mgm}$. in the 2 days following a dose, or approximately 55 per cent of the amount administered in the dose. The remainder presumably was stored in the body.

\section{Concentration in bile}

Interval specimens obtained from 1 patient in each group by duodenal drainage contained definite amounts of antimony. The concentration of antimony increased shortly after drug administration and then slowly decreased. 


\section{RESULTS OF TREATMENT}

Following the end of a course of treatment 92 of the 138 patients were followed by serial stool examinations (not less than 18 per patient) until the stools again became positive or for a period of 3 months if the stools remained negative. The various technics used on the same specimens consisted principally of the direct smear, gravity sedimentation, and centrifugalization methods. There were 33 patients treated with fuadin and, of these, 27 men, or 82 per cent, were again passing eggs within 3 months or less, after cessation of treatment. These 27 men were again treated with fuadin and 24 of them were again passing eggs in 3 months' time or less. Of the 59 patients treated with tartar emetic only 11 , or 19 per cent, were again passing eggs in their stools within 3 months or less.

\section{SUMMARY AND CONCLUSIONS}

1. The method of Maren for the determination of microgram quantities of antimony has been modified in order to make it more sensitive and specific. When 0.5 - to 5-microgram quantities of antimony were added to $5-\mathrm{ml}$. portions of plasma, urine, and blood and to 0.5 gram of feces they were recovered with an average error of less than 5 per cent.

2. One hundred thirty-eight patients were given 156 courses of treatment consisting of the administration on alternate days of tartar emetic or of fuadin equivalent to $45 \mathrm{mgm}$. of antimony. After 0.75 gram of antimony had been given in approximately 5 weeks the average plasma antimony concentration in both groups was about $100 \mathrm{mi}-$ crograms per liter. Four weeks later the concen- tration was 20 micrograms per liter. From 15 minutes to 4 hours after drug administration, the fuadin values were considerably greater than those of the tartar emetic group.

3. At all stages of treatment with both drugs the antimony concentration in the blood cells was definitely greater than that of plasma. For several hours after drug administration the tartar emetic group had decidedly higher blood cell concentrations than did the fuadin group.

4. The combined excretion in urine and feces toward the end of treatment was roughly $24 \mathrm{mgm}$. in 2 days or about 55 per cent of the amount administered in the preceding dose. The remainder presumably was stored in the body. Small amounts were still being excreted more than 100 days later.

5. Ninety-two patients were followed by serial stool examinations for an average of 3 months after completion of treatment. Within this period 82 per cent of 33 patients treated with fuadin were again passing eggs, whereas only 19 per cent of 59 patients treated with tartar emetic were again passing eggs.

6. The question is raised as to whether the higher antimony content in the red blood cells of patients treated with tartar emetic within the first 2 to 4 hours after drug administration than in those treated with fuadin is a factor in the greater therapeutic efficiency of this drug since it is known that the adult worms digest the host's erythrocytes. On the other hand, the known differences of distribution of the two drugs may be directly related to this question.

\section{BIBLIOGRAPHY}

1. Maren, T. H., The microdetermination of antimony. Bull. Johns Hopkins Hosp., 1945, 77, 338. 